\title{
Acquiring a Digital Audience for Theaters - Looking Through The Lenses of Customer Equity and Empirical Research
}

\author{
Paweł Kossecki \\ The Polish National Film, Television and Theater \\ School \\ ul. Targowa 61/63 \\ 90-323 Łódź, Poland \\ Email: kossecki@poczta.onet.pl
}

\author{
Urszula Świerczyńska-Kaczor \\ Jan Kochanowski University, Żeromskiego 5, 25-369 \\ Kielce Poland, \\ Email: swierczynska@ujk.edu.pl
}

\begin{abstract}
The aims of this paper are to: 1) outline and discuss the framework for linking theater e-marketing with customer equity; 2) assess the impact of digital theater services on the metrics connected with Customer Lifetime Value. The results of empirical research suggest that art-oriented young Internet-users, who do not attend traditional theaters, can be attracted to digital theater services. Digital services can influence the potential patron's engagement in the theater's website, favorable word-of-mouth, and also their intention to visit traditional performances.
\end{abstract}

\section{INTRODUCTION}

$\mathbf{M}$ arketing for performing arts organizations is mostly investigated through the lenses of the traditional marketing-mix, experience marketing or/and relationship marketing. As a new approach to marketing, based on customer equity, has been developing in the business sector (Blattberg \& Deighton 1996; Rust et al. 2004; Hogan et al. 2002), it is tempting to start a discussion about the contribution of this approach to marketing of the non-profit cultural sector.

In this paper the problem of acquiring a digital audience is placed within the boarder context of customer equity. It aims to: 1) outline and discuss the framework for linking theater e-marketing with customer equity; 2) assess the impact of digital theater services on the metrics connected with Customer Lifetime Value (and therefore customer equity), such as a patron's intention to purchase theater services and to spread positive word-of-mouth referrals.

The paper is organized as follows. In the next section we discuss the research problem and outline the research framework. The third section refers to the results of the questionnaire study. The article concludes with the summarized results.

\section{RESEARCH FRAMEWORK}

\section{A. The problem}

Relationship marketing aims to build the loyalty of patrons, increase patron retention rate and to shift customers from the status of 'potential customer' to the level of 'partner' and is perceived as the base of theater strategy (Rentschler et. al 2002; Quero 2007). Relationship marketing differs from the customer equity approach. Customer equity emphasizes the role of profitability of the customer (not all relationships should be maintained from the company's perspective), and customer equity approach is also useful for the situations while building strong relationship between the company and the customer is difficult (e.g. FMCG market).

In the case of the theater audience, customer equity marketing $^{1}$ relies on:

- Relationships build with patrons. Classic theaters rely on building a relationship with their patrons, and the consumers often repeat their purchases for years. Therefore there is a possibility to evaluate Customer Lifetime Value (CLV) at an individual level or segment level (as opposed to the situation where single purchases cannot be traced e.g. buying washing powder, and only segment level data is available for evaluating customer equity)

- The valuation of the segment of regular theatergoers. The segment of frequent theatergoers is often the core audience (see e.g. Instytut Teatralny "Raport - Badanie publiczności teatrów w stolicy” 2012; [http://www.instytutteatralny.pl/projekty/raporty; 05.04.2014],

\footnotetext{
Customer Equity Marketing is defined “[...] as a management approach for acquisition and retention, geared to individual lifetime values of current and future customers with the aim of continuously increasing Customer Equity” [Bayón et al. 2002, p. 214].
} 


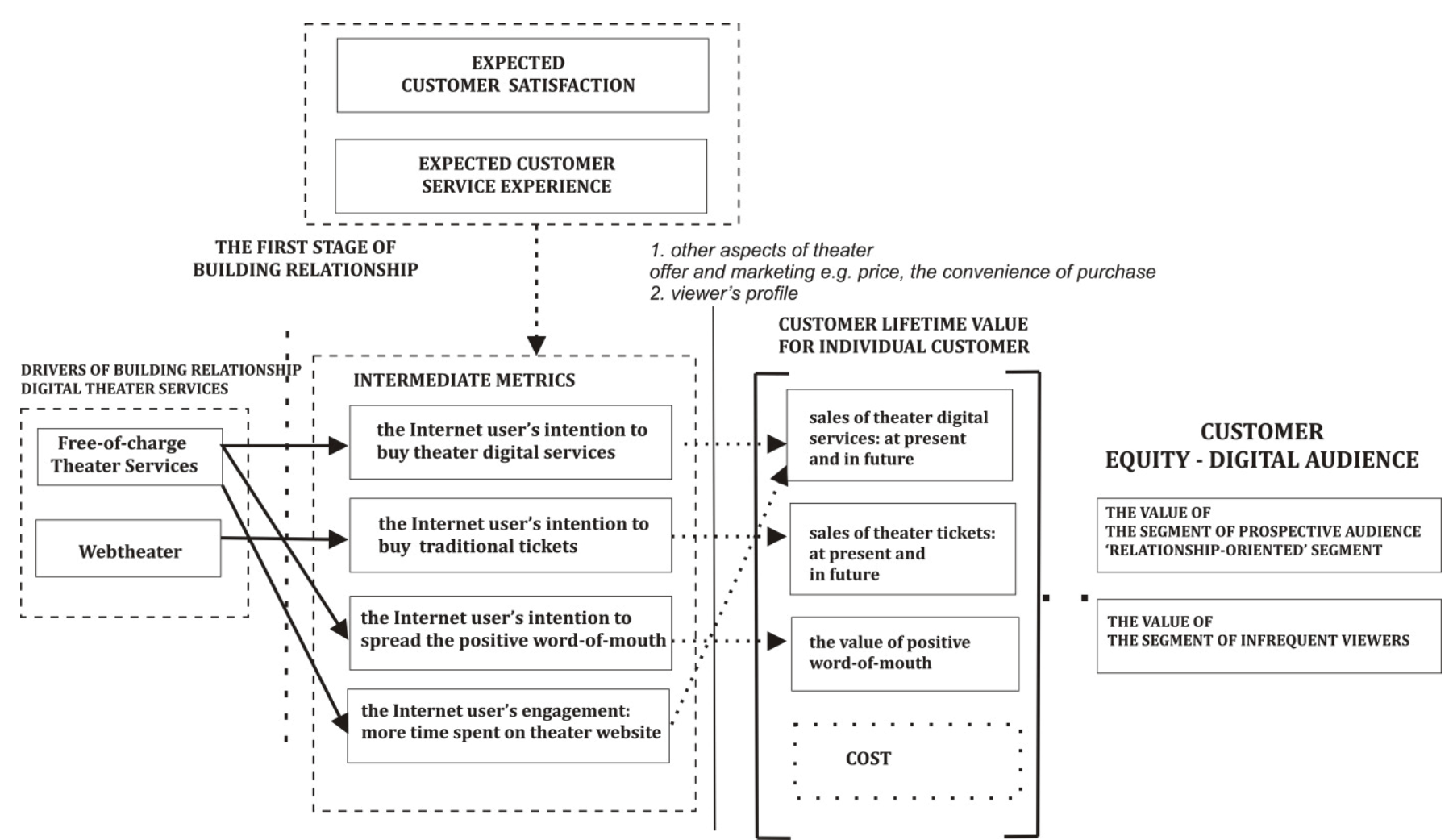

Fig. 1 The framework connecting theater e-marketing to customer equity

- Access to the data. The theater can often evaluate CLV at individual level (due to the data of subscribing patrons). The data referring to the market, such as number of viewers, number of performances, and cost of productions, is also often publicly available.

For overall theater strategy, customer equity management should be framed into boarder objectives such as objectives relating to artistic or curatorial quality, educational objectives, objectives relating to access for the public, objectives relating to knowledge, and social goals (Bakhshi \& Throsby 2012 pointed out five dimensions for non-profit cultural institution). The idea of looking through the lens of maximizing customer equity may shape the theater's strategic decisions especially in other-than-product areas e.g. the selection of promotional channels, in the process of customer service before and after performance, or additional theater services. The advantage of applying customer equity lens lies in the shift from the product-oriented perspective to the customer-oriented perspective. The customer equity management (if implemented) would also 'force' theaters to investigate and manage the drivers of customer equity.

There are different approaches to the spectrum of drivers influencing customer equity. In the model developed by Rust, Lemon and Zeithml, brand equity is one of the drivers of customer equity along with value equity and relationship equity (Rust et. al 2004). Other researches point out that the concept of brand equity and customer equity are not the same constructs, but they can be seen as two sides of the same coin - marketing activities leading to the influence of brand equity also influence customer equity and vice versa (Bick 2009; Leone et al. 2006).

In this paper we raise the question whether the implementation of e-marketing tools can impact the variables influencing the first phase of building a relationship with prospective digital viewers, and therefore their Customer Lifetime Value and customer equity (as indicated in the research framework - Fig.1). We focus on the Internet as a tool of attraction strategy for a few reasons. Firstly, the Internet plays a significant role in theater estrategy as:

1. The Internet facilitates innovation strategy for cultural organization in areas such as innovations in audience reach and in artform development, innovations in value creation and/or innovations in business management and governance (Bakhshi \& Throsby 2012);

2. Websites or use of social media can ease the effect of constrained availability and uncertain outcomes of a 'difficult' theatrical brand. The Internet allows the establishment of 'persistent presence of the theater brand in patrons' mind' and the creation of 'small worlds - communities of performing art patrons' (see Preece \& Johnson 2011);

3. The Internet can be effectively used in improving the responsiveness of theaters to different stakeholders, in enhancing the image, in attracting volunteers or sponsors and in selling tickets (Turrini et. al. 2012);

4. Social media can support marketing in the area of promotion and communication, word-of-mouth referrals, market research and innovation 
management, and in reputation management (Hausmann \& Poellmann 2013).

Moreover, as there is a steady decline in participation in art events and also with the problem of aging audiences (Turrini et al. 2012), the Internet allows theaters to reach young people, who are uninterested in traditional theater, but may become the theater audience within cyberspace. We assume that winning over a young audience in the competitive market of leisure activities needs 'the most untraditional approach'. Therefore in the empirical study we included the concept of theater services which are not only interactive, but break with the traditional perception of the role of the viewers. The tested concepts of new digital theater services are:

- free-of-charge digital products such as newsletters, ebooks about theater, webseminars about theater, webseminars about acting, gadgets connected with the theater, job posts, marketing research reports about theater;

- webtheater - the new artform which was described to each respondent as a possible option embedded on the website. So far, the live broadcasts of art performances (such as concerts, opera or even theater performance) lack the basic value of virtual communication, as they do not allow the spectator to co-create the product. The idea of the webtheater performance is based on co-creation of the play the Internet-user can influence the flow of the performance by voting online on selected decisions e.g. the Internet-user can decide the fate of the main hero. Therefore the second part of the performance depends on the audience's decisions.

We assume that the Internet lowers the threshold of building the relationship between the prospective young viewers and the theater. For traditional performances " $[t] h e$ organization invests time, money and commitment to its mission to give the patron a rewarding experience. The audience also invests time, money and an emotional and social commitment in the arts organization." (Rentschler et. al 2002, p. 124). The Internet allows audiences to 'try' digital theater services, and makes theater attendance more convenient for young, digital audience. Is it 'the same theater' as traditional theaters from the aspect of the customer's experience? Probably not, but if traditional theatres do not attract young audiences, maybe 'digital theater' would meet their needs and enable the beginning of a young audience's relationship with traditional theater.

The customer equity approach raises questions about the drivers of customer equity for digital theater. We assume that the value of customers visiting the theater website (with developed interactive services) would be connected with at least:

1. financial value connected with direct purchases on the Internet e.g. tickets or other theater products (e.g. gadgets, ebooks);

2. indirect value connected with: a. enhancing the attractiveness of the website for advertisers (more engaged visitors stay longer on the website, probably paying more attention to its content including advertisements);

b. Internet-user's referrals (performance, the theater website itself) to others;

c. Internet-user's contribution, such as expressing and sharing opinions, which allows for improvement to the theater services (we did not capture this construct in the study).

\section{B. The framework of empirical survey}

The conducted survey was an exploratory study, and at this point of the research we focused on a selected problem the link between online theater marketing and the rate of acquiring digital patrons. Therefore not all of the interrelations indicated in framework Fig. 1 were investigated.

We based the survey on a "what-if" scenario, while respondents were asked to what extent the new forms of free-of-charge services and interactive theater (webtheater) attracts their attention and influences their intention to purchase paid products.

In the study we measured the Internet-user's intention to purchase or consume the theater website services, assuming that strong intention leads to real purchase - if other aspects of the theater offer will be acceptable for the Internet user. The measured metrics, such as intention to buy theater services or tickets, the intention to recommend theater services or to be engaged on theater website, are linked with Internet-user's perception of service experience and expected satisfaction.

We want to emphasize that:

- we test the concept of digital theater services, not of developed and produced digital products;

- we do not include the costs, as the cost is 'unpredictable' at this point of research;

- the constructs of expected Internet-user' satisfaction, and perception of the expected experience are boarder than 'intentions' measured; although we presume that the user's intentions are linked with these constructs. 
TABLE I.

THE QUESTION: NOWADAYS MOST THEATERS HAVE THEIR OWN WEBSITES, FACEBOOK, GOOGLE PLUS, TWITTER PAGE OR RUNNING BLOG. IF THE THEATER EMBEDDED THE FOLLOWING INTERNET SERVICES AND OFFERED THEM FREE-OF-CHARGE, HOW THIS WOULD

AFFECT YOUR VISIT TO THE THEATER WEBSITE E.G. YOU SPEND MORE TIME ON THEATER WEBSITES ON A MONTHLY BASIS DUE TO VISITING MORE OFTEN OR TO CONSUMING MORE CONTENT OF THE WEBSITE? IF THESE SERVICES WHERE TO BE PAID FOR, HOW IT WOULD AFFECT YOUR ATTITUDE?

\begin{tabular}{|c|c|c|c|c|c|c|c|}
\hline \multirow{2}{*}{\multicolumn{2}{|c|}{$\begin{array}{l}\text { The theater offer: } \\
\text { Group OT 'Out of target market } \\
\quad n=37 \\
\text { Group AO 'art-oriented' } n=45 \\
\text { Group FS 'filmschool students' } \\
\quad n=44 \\
\end{array}$}} & \multicolumn{3}{|c|}{ Free-of-charge } & \multicolumn{3}{|c|}{ Paid content } \\
\hline & & \multirow[t]{2}{*}{$\begin{array}{l}\text { Negative } \\
\mathbf{1 - 2} \\
59.5 \% \\
\end{array}$} & \multirow{2}{*}{$\begin{array}{l}\text { Positive } \\
\text {-5 } \\
29.7 \% \\
\end{array}$} & \multirow[t]{2}{*}{$\begin{array}{l}\begin{array}{l}\text { Average } \\
(\mathbf{1 - 5})\end{array} \\
2.5 \\
\end{array}$} & \multirow[t]{2}{*}{$\begin{array}{l}\begin{array}{l}\text { Negative } \\
\text { (1-2) }\end{array} \\
89.2 \%\end{array}$} & \multirow[t]{2}{*}{$\begin{array}{l}\begin{array}{l}\text { Positive } \\
(4-5)\end{array} \\
2.7 \% \\
\end{array}$} & \multirow[t]{2}{*}{$\begin{array}{l}\begin{array}{l}\text { Average } \\
(1-5)\end{array} \\
1.4 \\
\end{array}$} \\
\hline e-book about theater & OT & & & & & & \\
\hline & $\mathrm{AO}$ & $20.0 \%$ & $62.2 \%$ & 3.7 & $76.6 \%$ & $15.6 \%$ & 2.0 \\
\hline & FS & $36.4 \%$ & $40.9 \%$ & 3.2 & $77.3 \%$ & $11.4 \%$ & 1.8 \\
\hline \multirow{3}{*}{$\begin{array}{l}\text { webseminar about } \\
\text { theater }\end{array}$} & OT & $64.9 \%$ & $13.5 \%$ & 2.1 & $83.8 \%$ & $5.4 \% \%$ & 1.5 \\
\hline & $\mathrm{AO}$ & $40.0 \%$ & $31.1 \%$ & 2.9 & $73.3 \%$ & $13.3 \%$ & 2.0 \\
\hline & FS & $47.7 \%$ & $29.5 \%$ & 2.8 & $72.7 \%$ & $13.6 \%$ & 1.8 \\
\hline \multirow{3}{*}{$\begin{array}{l}\text { e-report about } \\
\text { theater market }\end{array}$} & OT & $54.1 \%$ & $35.1 \%$ & 2.6 & $89.2 \%$ & $10.8 \%$ & 1.6 \\
\hline & $\mathrm{AO}$ & $40.0 \%$ & $37.8 \%$ & 3.0 & $77.8 \%$ & $22.2 \%$ & 2.0 \\
\hline & FS & $50.0 \%$ & $29.5 \%$ & 2.7 & $88.6 \%$ & $6.8 \%$ & 1.6 \\
\hline \multirow{3}{*}{$\begin{array}{l}\text { job posts connected } \\
\text { with theater }\end{array}$} & OT & $32.4 \%$ & $45.9 \%$ & 3.1 & $73.0 \%$ & $16.2 \%$ & 1.9 \\
\hline & $\mathrm{AO}$ & $24.4 \%$ & $51.1 \%$ & 3.4 & $75.6 \%$ & $20.0 \%$ & 2.1 \\
\hline & FS & $9.1 \%$ & $65.9 \%$ & 4.0 & $88.6 \%$ & $2.3 \%$ & 1.5 \\
\hline \multirow[t]{3}{*}{ gadgets } & OT & $32.4 \%$ & $51.4 \%$ & 3.3 & $70.3 \%$ & $18.9 \%$ & 2.1 \\
\hline & $\mathrm{AO}$ & $17.8 \%$ & $66.7 \%$ & 3.9 & $51.1 \%$ & $33.3 \%$ & 2.6 \\
\hline & FS & $29.5 \%$ & $40.9 \%$ & 3.2 & $72.7 \%$ & $6.8 \%$ & 1.8 \\
\hline \multirow{3}{*}{$\begin{array}{l}\text { webseminar about } \\
\text { acting }\end{array}$} & OT & $45.9 \%$ & $35.1 \%$ & 2.6 & $59.5 \%$ & $21.6 \%$ & 2.3 \\
\hline & $\mathrm{AO}$ & $22.2 \%$ & $64.4 \%$ & 3.8 & $48.9 \%$ & $44.4 \%$ & 3.0 \\
\hline & FS & $43.2 \%$ & $31.8 \%$ & 2.9 & $79.5 \%$ & $11.4 \%$ & 1.8 \\
\hline \multirow{3}{*}{$\begin{array}{l}\text { e-newsletter about } \\
\text { theater }\end{array}$} & OT & $100 \%$ & - & 1.4 & $89.2 \%$ & $2.7 \%$ & 1.4 \\
\hline & $\mathrm{AO}$ & - & $100 \%$ & 4.5 & $62.2 \%$ & $26.7 \%$ & 2.4 \\
\hline & FS & $20.5 \%$ & $54.5 \%$ & 3.5 & $81.8 \%$ & $6.8 \%$ & 1.7 \\
\hline
\end{tabular}

\section{The data and the sample}

Although the construct of customer equity as a value of the customer base is agreed, there is no consensus on how to calculate it and what drivers influence customer equity and what intermediate constructs and metrics should be used to assess customer equity. Kumar \& George (2007) point out that the approaches to calculate customer equity which appear in literature can be divided into two main streams:

- aggregate-level approaches evaluate customer equity using customer life time value (CLV) for a segment or "average CLV" in the company. Therefore these methods focus on segment- or firm- level, and on such metrics as the acquisition rate, the average average contribution margin or the average CLV from a sample;

- disaggregate-level approach is based on the sum of the calculated individual CLVs, therefore this approach needs to be based on detailed and individual level data.
In our study we collected the data from the sample of individual respondents who filled in the questionnaire. As we do not have the data connected with costs, we concentrated on assessing the customers' willingness to purchase the product and in spreading positive word-ofmouth recommendations.

Our approach to Customer Lifetime Value refers to the model proposed by Kossecki $(2007,2011)$ in which CLV for individual customer $\mathrm{c}$ is evaluated as:

$$
\mathrm{CLV}_{\mathrm{C}}=\sum_{\mathrm{t}=0}^{\mathrm{CL}} \frac{\mathrm{P}_{\mathrm{t}}}{(1+\mathrm{r})^{\mathrm{t}}}
$$

$P_{t}$-profit per individual user in $t$-period. This profit should be understood as financial profit coming 
from two sources: direct purchases and positive word-of-mouth

$C L$ - customer lifetime

$\mathrm{r}$ - discount rate;

From an aggregated level perception the digital audience can be divided into segments according to their willingness to build a relationship with the theater. The customers who focus on 'one-time' contact with theater (e.g. interested in receiving free-of-charge theater digital gadgets) are less valuable than the relationship-oriented customers. Valuation of the customers of the 'one-deal' segment may be based on such metric as the profit per transaction, but the CLV approach is more suitable for the segment of 'relationshiporiented' customers (Kossecki 2007; Kossecki 2011).

In the survey we implemented a questionnaire which was distributed in January 2014 among 146 respondents, within two different groups of young adults (under the age of 30 years-old): the students of a filmschool in Poland (whom we regarded as experts in the field of theater production, $n=44$ ) and students of business studies (whom we regarded as nonexperts, $n=102$ ). There is a significant difference between the filmschool students and the business students in attendance to classic theaters (test U Mann-Whitney, $\mathrm{p}<0.05)$ : both in the variable 'when last theater visit occurred' and the variable 'frequency of visiting theater during last year'. Most of the filmschool students attended classic theaters more than once during the last year $(20 \%$ of filmschool students attended more than 3 times). In contrast, $76 \%$ of business students did not take part in theater performances for the last year, and $17 \%$ attended only once during the last year. In the study this group of business students is considered as the group of 'potential audience', who rarely or not at all attend classic theater. In the study we did not capture the socio- and demographical profile of respondents, but the sample is homogenous with the age of respondents.

D.Hypothesis

The framework for research (Fig. 1) leads to following hypotheses:
- Hypothesis 1: - The free-of-charge Internet services embedded on a theater website enhance customer's engagement

- Hypothesis 2: Free-of-charge Internet services embedded on a theater website enhance the sale of paid products.

- Hypothesis 3: The free-of-charge Internet services embedded on a theater website enhance customer referrals

- Hypothesis 4: The new digital interactive artform 'webtheater' enhances the customer's willingness to buy traditional tickets

We arbitrarily agreed that the percentage of the 'prospective audience' which we would consider as 'significant enough' to justify theater efforts to develop digital services should be at least $51 \%$ of the sample for services offered free-of-charged and at least $30 \%$ of the sample for paid theater services.

\section{THE RESULTS}

A. User's interest in subscribing to free-of-charge newsletters about theater is an important factor in market segmentation.

In the questionnaire the respondents were asked if they would be interested in subscribing to a newsletter about the theater. Among the group of 'potential audience' $(n=102)$ $36 \%$ declared that they would not be willing to subscribe the e-newsletter ( 1 o 2 on the scale 1-5), 20\% expressed a neutral statement ( 3 on the scale), and $44 \%$ stated that they are willing to accept the newsletter (4-5 on the scale). Further analysis showed that this factor - acceptance of newsletter subscription - can be used as a segmentation criterion of the potential audience. The group with lowest and the group of the highest acceptance of subscription perceived theater services differently (Table I). Therefore among the group of 'potential young audience' we identified the segment called 'art-oriented segment' (AO), and the segment of young people who are uninterested in classic theater and seems to be outside the possible reach as the theater audience ('out of target market' - OT).

TABLE II.

THE CORRELATION BETWEEN THE INTENSIONS TO USE FREE-OF-CHARGE THEATER SERVICE AND INTENTION TO PURCHASE THE SAME PAID SERVICE - SPEARMAN, $\mathrm{P}<0.05$

\begin{tabular}{|l|l|l|l}
\hline & \multicolumn{1}{|c|}{$\begin{array}{c}\text { Young adults (general) } \\
(\mathbf{n = 1 0 2})\end{array}$} & \multicolumn{1}{c}{$\begin{array}{c}\text { Art-oriented segment } \\
(\mathbf{n = 4 5})\end{array}$} & $\begin{array}{c}\text { Filmschool students } \\
(\mathbf{n = 4 4 )}\end{array}$ \\
\hline e-book about theater & 0.28 & 0.30 & 0.61 \\
\hline webseminar about theater & 0.44 & 0.45 & 0.64 \\
\hline $\begin{array}{l}\text { e-report about theater market (e.g. audience market } \\
\text { research) }\end{array}$ & 0.28 & - & 0.33 \\
\hline job posts connected with theater & 0.30 & - & - \\
\hline gadgets & 0.39 & 0.36 & 0.46 \\
\hline webseminar of acting & 0.54 & 0.66 & 0.57 \\
\hline e-newsletter about theater & 0.39 & - & 0.45 \\
\hline
\end{tabular}


TABLE III.

WOULD YOU RECOMMEND THE THEATER WEBSITE IF...

\begin{tabular}{|l|l|l|l|l|l|}
\hline \multicolumn{2}{|c|}{} & $\begin{array}{l}\text { Negative } \\
(\mathbf{1 - 2})\end{array}$ & $\begin{array}{l}\text { Neutral } \\
(\mathbf{3})\end{array}$ & $\begin{array}{l}\text { Positive } \\
(\mathbf{4 - 5})\end{array}$ & Average \\
\hline \multirow{3}{*}{$\begin{array}{l}\text { the theater offers free services (these } \\
\text { as indicated previously) }\end{array}$} & Art-oriented segment (n=45) & $17.8 \%$ & $8.9 \%$ & $73.3 \%$ & 4.0 \\
\cline { 2 - 6 } & Out-of-target (n=37) & $29.7 \%$ & $8.1 \%$ & $62.2 \%$ & 3.7 \\
\cline { 2 - 6 } & Filmschool (n=44) & $18.2 \%$ & $18.2 \%$ & $63.6 \%$ & 3.8 \\
\hline \multirow{3}{*}{$\begin{array}{l}\text { the theater offers paid services (these } \\
\text { as indicated previously) }\end{array}$} & Art-oriented segment (n=45) & $64.4 \%$ & $20.0 \%$ & $15.6 \%$ & 2.2 \\
\cline { 2 - 6 } & Out-of-target (n=37) & $73.0 \%$ & $18.9 \%$ & $8.1 \%$ & 1.9 \\
\cline { 2 - 6 } & Filmschool (n=44) & $59.1 \%$ & $22.7 \%$ & $18.2 \%$ & 2.3 \\
\hline
\end{tabular}

As the respondents were asked about their intention to visit theater websites on a regular basis (more visits, more consumed content in the month), this 'art-oriented' customers can be also regarded as 'the relationship-oriented' segment of internet users.

B. Hypothesis 1: The free-of-charge Internet services embedded on the theater website enhance customer engagement

The results indicate that a young audience can be attracted to the theater website as the result of offering free-of-charge theater services (Table I). Not surprisingly young people value the services as being useful in their potential jobs, such as webseminars about acting (public presentation is part of the modern job) or posts about jobs. Free gadgets attract the majority of users to the theater website. There are differences between the perception of website content by fimschool students and business students. It can be explained by access to other information sources with similar content (e.g. easier access to other materials connected with general art by filmschool students).
The percentage of art-oriented users attracted by theater services differs depending on the particular product, e.g. webseminars about theater attract about $30 \%$ of the potential audience; webseminars about acting, about 60\%, with similar percentages for free-of-charge gadgets and e-books about theater. Among the art-oriented segment the average percentage of Internet-users willing to use free-of-charge services is $52 \%$ (compared to $35 \%$ of the "out of the target" segment).

C. Hypothesis 2: Free-of-charge Internet services embedded on theater websites enhance the sale of paid products.

Although the young audience is not very likely to buy services offered by the theater (Table I), the percentage of art-oriented internet-users willing to buy theater services ranges from $13 \%$ (webseminars about theater) to $44 \%$ (webseminars about acting). For this segment the average percentage of users willing to purchase theater services is $23 \%$.

The correlation between the user's interest in free-ofcharge services and willingness to purchase one is quite

TABLE IV.

THE PERCEPTION OF INTERACTIVE THEATER -WEBTHEATER. QUESTION: DO YOU THINK THAT TAKING PART IN WEBTHEATER YOU FEEL...

\begin{tabular}{|l|l|l|l|l|}
\hline & $\begin{array}{l}\text { Art-oriented } \\
\text { segment }(\mathbf{n = 4 5})\end{array}$ & $\begin{array}{l}\text { Out of target } \\
(\mathbf{n = 3 7})\end{array}$ & $\begin{array}{l}\text { Young audience } \\
\text { (general) (n=102) }\end{array}$ & $\begin{array}{l}\text { Filmschool } \\
\text { Students (n=44) }\end{array}$ \\
\hline The sense of belonging to theater community & 3.2 & 2.5 & 2.9 & 3.0 \\
\hline Being immersed in storytelling & 3.3 & 3.0 & 3.1 & 3.0 \\
\hline Reflection connected with art performance & 3.5 & 2.8 & 3.2 & 3.8 \\
\hline Being with creative people & 3.0 & 2.8 & 2.9 & 2.9 \\
\hline Taking part in special event & 3.5 & 2.6 & 3.1 & 3.3 \\
\hline Intensive esthetic experience & 3.0 & 2.5 & 2.8 & 2.7 \\
\hline Spending free time in meaningful way & 3.6 & 3.5 & 3.6 & 3.5 \\
\hline Intensive emotion & 3.5 & 2.8 & 3.3 & 2.9 \\
\hline The feeling of discovering the world & 3.3 & 2.8 & 3.0 & 2.7 \\
\hline Intellectual challenge & 3.4 & 3.1 & 3.2 & 3.1 \\
\hline Personal growth & 3.8 & 3.3 & 3.6 & 3.0 \\
\hline Feeling being together with others during event & 3.6 & 2.8 & 3.3 & 3.0 \\
\hline
\end{tabular}


TABLE V.

QUESTIONS: DO YOU AGREE WITH THE FOLLOWING STATEMENTS

\begin{tabular}{|c|c|c|c|c|}
\hline & \multirow{2}{*}{$\begin{array}{c}\begin{array}{c}\text { Young } \\
\text { audience } \\
(\mathbf{n}=\mathbf{1 0 2})\end{array} \\
\text { average }(1-5) \\
\end{array}$} & \multicolumn{2}{|c|}{$\begin{array}{l}\text { Art-oriented users } \\
\qquad(\mathrm{n}=45)\end{array}$} & \multirow{2}{*}{$\begin{array}{c}\begin{array}{c}\text { Filmschool } \\
\text { Students } \\
(\mathrm{n}=44)\end{array} \\
\text { average }\end{array}$} \\
\hline & & average (1-5) & positive opinion (4-5) & \\
\hline The idea of webtheater sounds interesting to me & 3.3 & 3.6 & $64.4 \%$ & 3.4 \\
\hline I would like participate in such event & 3.3 & 3.6 & $55.6 \%$ & 3.3 \\
\hline $\begin{array}{l}\text { Webtheater allows me to take part in theatrical } \\
\text { performance more often }\end{array}$ & 3.6 & 3.8 & $62.2 \%$ & 3.2 \\
\hline Webtheater is a good idea for art promotion & 3.6 & 3.6 & $62.2 \%$ & 3.9 \\
\hline $\begin{array}{l}\text { Webtheater encourages me to watch the performance in } \\
\text { traditional theater }\end{array}$ & 3.4 & 3.6 & $66.7 \%$ & 3.1 \\
\hline
\end{tabular}

strong among filmschool students; weaker among other respondents (Table II). It is especially worth noticing that offering free gadgets does not necessary lead to the purchase of one (there is a weak positive correlation). As an exception we can point to webseminars - in this case using free-ofcharge webseminars about actors performing can probably lead to buying a paid one.

D.Hypothesis 3: The free-of-charge Internet services embedded on theater websites enhance Internet-user referrals

About $73 \%$ of Internet users from the 'art-oriented' segment declared that they recommend the theater website to others if the website includes free-of-charge services. The percentage drops to about $16 \%$ in the case of offering paid products (Table III).
E. Hypothesis 4: The new digital interactive artform 'webtheater' enhances the customer's willingness to buy traditional tickets

The digital theater (webtheater) was assessed by respondents in two areas: their perception of the expected experience connected with attending a digital theater (Table IV) and their general assessment of this idea (Table V).

The respondents assessed their expected experience in 12 dimensions (see - Walmsley 2011). The art-oriented viewers valued their experience highly in the following dimensions: personal growth, the feeling being together with others during the event, spending free time in a meaningful way, taking part in special event, intensive emotions and reflection connected with art performance. This aspect of digital webtheater needed to be explored more, and further, with much deeper research. For our purpose, the main conclusion is that the idea of a new digital interactive theater was not rejected by the young possible audience.

In the second area, respondents were asked if the

TABLE VI.

SUMMARIZED RESULTS

\begin{tabular}{|l|l|l|l|}
\hline & Out-of-target segment & \multicolumn{1}{|c|}{ Art-oriented users } & \multicolumn{1}{|c|}{ Filmschool students } \\
\hline $\begin{array}{l}\text { H1: The free-of-charge Internet services embedded } \\
\text { on theater website enhance customer's engagement } \\
\text { [at least 51\% of the sample expressed a positive } \\
\text { opinion towards using particular free-of-charge } \\
\text { service] }\end{array}$ & Confirmed for gadgets & $\begin{array}{l}\text { Confirmed for e-book, } \\
\text { gadgets, jobs posts, } \\
\text { webseminar about acting }\end{array}$ & $\begin{array}{l}\text { Confirmed for job posts, e- } \\
\text { newsletters }\end{array}$ \\
\hline $\begin{array}{l}\text { H2: Free-of-charge Internet services embedded on } \\
\text { theater website enhance the sale of the paid products } \\
\text { [at least 30\% of the sample expressed a positive } \\
\text { opinion towards buying paid content and there is at } \\
\text { least a medium positive correlation between using } \\
\text { the free-of-charge content and the intention to } \\
\text { purchase] }\end{array}$ & Rejected & $\begin{array}{l}\text { Confirmed for } \\
\text { webseminars about } \\
\text { acting }\end{array}$ & Rejected \\
\hline $\begin{array}{l}\text { H3: The free-of-charge Internet services embedded } \\
\text { on theater website enhance internet user's referrals } \\
\text { [at least 51\% of the sample expressed a positive } \\
\text { opinion] }\end{array}$ & Confirmed & Confirmed & Confirmed \\
\hline $\begin{array}{l}\text { H4: The new digital interactive artfom 'webtheater' } \\
\text { enhances the customer willingness to buy traditional } \\
\text { tickets } \\
\text { [at least } 51 \% \text { of the sample expressed a positive } \\
\text { attitude about watching traditional performance }]\end{array}$ & Rejected & & Rejected \\
\hline
\end{tabular}


webtheater influences their willingness to attend traditional theater performances. About $67 \%$ of the art-oriented users declared that the digital performance sparks their interest in visiting a traditional theater.

\section{CONCLuSiOns}

The summarized results of empirical study (Table VI) suggest that the theater strategy of audience broadening (attracting a new group of audience) can be based on offering free-of-charge services and offering the new artform of webtheater. The main conclusions are:

- The digital theater services mainly attracted the 'artoriented' young people, and this segment of potential digital audience can also be perceived as the 'relationship-oriented' segment.

- The results underline the importance of the e-newsletter as a digital tool aiming to create a relationship with a patron.

- The sale of paid content is not driven by offering free-ofcharge content. At this point of the research we may presume that customer equity for theater website may be based mostly on indirect values such as a patron's referrals and engagement.

- Free-of-charge digital content on the theater website can influence positive word-of-mouth referrals.

However, the presented results should be further investigated as our research has at least the following limitations:

- The data is based on the convenient sample, and therefore it is difficult to generalize the results for a larger population. On the other hand, the Internet rarely allows researchers to base a survey on a more controlled sample (with the possibility of verifying the identity of the user).

- As we tested the concept of digital services we did not include the cost connected with the digital offer.

- We based this study on the assumption that a declared intention to buy leads to a real purchase.

- We did not differentiate between the theater brand and the theater website brand, assuming that these constructs are very close related;

- We did not include socio- and demographical profiles of respondents into the analysis e.g. current consumption of art, the income or the place of living.

Customer equity management for the cultural sector is the under-researched area, in which deeper theoretical and empirical research is needed. We consider of particular importance, further investigation into the following problems:

- Developing the framework outlined in this paper, aiming at building a CLV model - which would be applicable for theaters.

- Identification of the spectrum of drivers of customer equity in theaters;

- Further research about the concept of webtheater. This new product - allowing the patrons to shape the digital theater performance - raises the question not only about the possible income connected with the sale of tickets, but also about the patron's new experience.

- The connection between Internet-audience equity and traditional theater-audience equity.

\section{REFERENCES}

1] Bakhshi H., Throsby D. (2012), "New technologies in cultural institutions: theory, evidence and policy implementation", International Journal of Cultural Policy, Vol. 18, No. 2, March 2012, 205-222.

[2] Bayón T., Gutsche J., Bauer H. (2002), "Customer Equity Marketing: Touching the Intangible", European Management Journal, Jun2002, Vol. 20, No. 3, 213-222.

[3] Bick G. N. C. (2009), "Increasing shareholder value through building Customer and Brand Equity", Journal of Marketing Management, Vol. 25, No .1-2, 117-141.

[4] Blattberg R. C., Deighton J. (1996), "Manage Marketing by the Customer Equity Test”, Harvard Business Review, Jul/Aug 1996, Vol. 74, Issue 4, 136-144.

[5] Hausmann A., Poellmann L. (2013), "Using social media for arts marketing: theoretical analysis and empirical insights for performing arts organizations", International Review on Public and Nonprofit Marketing, (2013), Vol. 10, 143-161.

[6] Hogan J. E., Lemon K. N., Rust R. T. (2002), "Customer Equity Management. Charting New Directions for the Future of Marketing", Journal of Service Research, Vol. 5, No. 1, August 2002, 4-12.

[7] Instytut Teatralny "Raport - Badanie publiczności teatrów w stolicy" 2012; [http://www.instytut-teatralny.pl/projekty/raporty; 05.04.2014].

[8] Kossecki P. (2007), „Wartość życiowa klientów i jej zastosowanie do wyceny przedsiębiorstw internetowych", Problemy Zarzadzania, 3/2007 (17), 78-88.

[9] Kossecki P. (2011) „Kreowanie i pomiar wartości przedsiębiorstwa w świecie Internetu", Wydawnictwo Państwowej Wyższej Szkoły Filmowej, Telewizyjnej i Teatralnej im. L. Schillera w Lodzi.

[10] Kumar V., George M. (2007), "Measuring and Maximizing custome equity: a critical analysis", Journal of the Academy of Marketing Science, (2007), Vol. 35, 157-171.

[11] Leone R. P., Rao V.R., Keller K. L., Luo A. M., McAlister L., Srivastava R. (2006), "Linking Brand Equity to Customer Equity", Journal of Service Research, November 2006, Vol. 9, No. 2, 125-138.

[12] Preece S. B, Wiggins Johnson J. (2011), "Web Strategies and the Performing Arts: A Solution to Difficult Brands", International Journal of Arts Management, Vol. 14, No. 1, Fall 2011, 19-31.

[13] Quero M. J. (2007), "Relationship Marketing And Services Marketing: Two Convergent Perspectives For Value Creation In The Cultural Sector. Empirical Evidence On Performing Arts Consumers In Spain", International Review on Public and Non Profit Marketing, Vol. 4, No 1/2 (December 2007), 101-115

[14] Rentschler R., Radbourne J., Carr R., Rickard J. (2002), Relationship marketing, audience retention and performing arts organization viability", International Journal of Nonprofit and Voluntary Sector Marketing, Vol. 7, No. 2, 118-130.

[15] Rust R. T.; Lemon K. N.; Zeithaml,V. A. (2004), "Return on Marketing: Using Customer Equity to Focus Marketing Strategy", Journal of Marketing, Jan2004, Vol. 68 Issue 1, 109-127.

[16] Walmsley B. (2011), "Why people go to the theater: A qualitative study of audience motivation", Journal of Customer Behaviour, 2011, Vol. 10, No. 4, 335-351. 